\title{
SADDAM HUSSEIN'S TRIAL: THE AMERICAN HEGEMONY AND A GOOD WORLD GOVERNANCE TRAGEDY
}

\author{
By: Faiz Tajul Millah*
}

\section{Abstract}

After the destruction of the U.S. World Trade Center on September 11, 2001, America was focusing its international political policy on war on terrorism which was further followed by preemptive action and unilateralism toward countries considered as terrorists. One of them is Iraq. Certainly the policy will obstruct the realization of good world governance under the United Nations Program. Attacking Iraq in 2003 was a real proof of the U.S. hegemony over the world as the Super Power country, especially concerning Saddam Hussein's judicial process which was held by the Iraqi Special Tribunal which was under the U.S. intervention. Theoretically, the judicial process of Saddam Hussein's case who was accused of genocide toward Kurdish should be held by the International Criminal Court (ICC) under the United Nations. It was not the competence of the Iraqi Special Tribunal. Saddam Hussein's trial was invalid and violated the principals of international law. This case would obstruct the enforcement of international law supremacy which is one of the requirements of good world governance. Since international politics is under the U.S. hegemony, the realization of good world governance is in jeopardy.

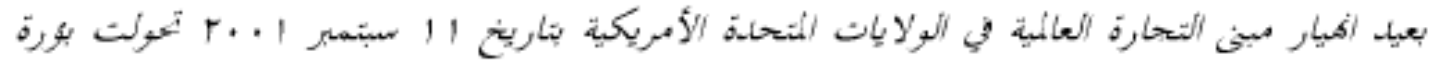

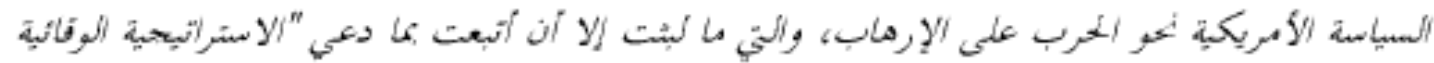

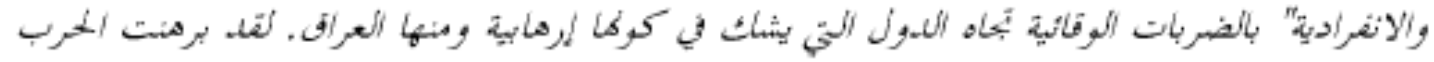

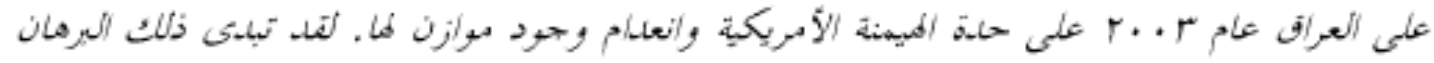

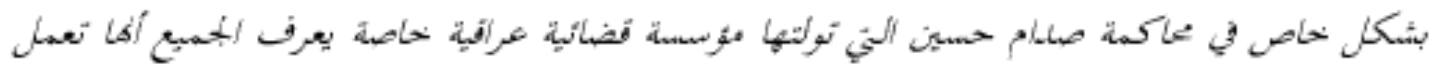

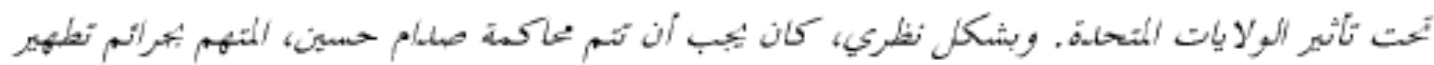

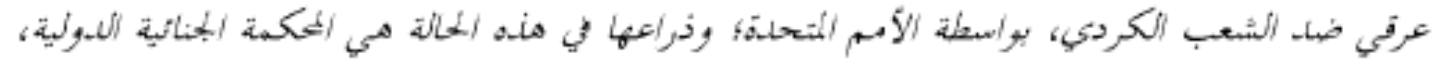

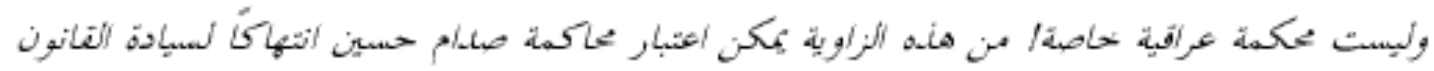

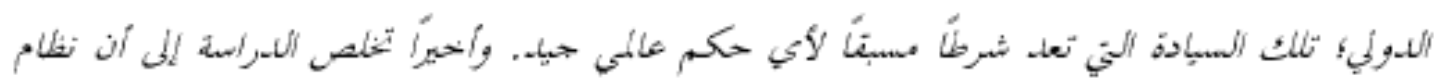

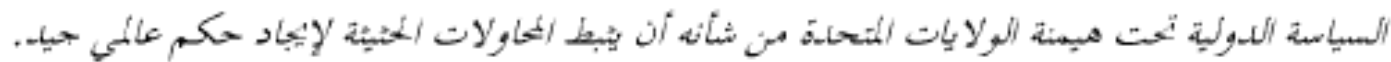


Keywords: Governance, politics, hegemony, and law supremacy

\section{A. Introduction}

The destruction of the World Trade Center in the United States on September 11, 2001, had woken American elite politics that their national security was in danger, despite American political dominance throughout the world. The U.S.'s power has manifested throughout the world into economy, culture, science, technology, weaponry and intelligent supremacy.

As a superpower country has existed since the Cold War, America has a strong influence upon other countries as well as international relationship. Its intervention in Iraqi political alteration proved American's influence upon the rest of the world. John Ikenbery states that:

"No one disagrees that U.S. power is extraordinary. It is the character and logic of U.S. domination that is at issue in the debate over empire. The United States is not just a superpower pursuing its interest; it is a producer of world order." ${ }^{\text {"1 }}$

The US's president, George H.W. Bush (Bush senior), declared The New World Order in 1990s which meant the establishment of a global and democratic system. This doctrine continued to be promoted by George W. Bush (Bush junior), especially after the WTC tragedy on September 11, 2001. Under Bush's presidency, the U.S. firmly stated that the world has changed.

American policy was directed towards the war against terrorism and implementing unilateralist policy. In alliance with Britain and Australia, the U.S. established a coalition to promote war on terrorism including applying the economic embargo and sending military action against terrorism to terrorist's hideout countries.

This new means of war has been imposed intensively by American government. In

* The author is an alumnus of Center for Religious and Cross-Cultural Studies (CRCS), Gajah Mada University, Yogyakarta

${ }^{1}$ G. John Ikenberry (2004), "Illusions of Empire: Defining the New American Order”, in Foreign Affairs, Vol. 83, No. 2, March/April 2004, p. 145 
his speech before the U.S. Congress on September 20, 2001, George W. Bush gave an ultimatum to the world that:

"Every nation in every region now has a decision to make: either you are with us or you are with the terrorist. From this day forward, any nation that continues to harbor or support terrorism will be regarded by the United States as a hostile regime."2

His statement clearly put the U.S. as the just country and whoever stands against them is the axis of evil. In this case, the U.S. considered Iraq, Iran and South Korea as the axis of the evil.

Iraq, one of the countries suspected to have developed weapons of mass destruction (WMD) illegally and to support the terrorist group Al-Qaida, was the primary target for the war on terrorism. At that time, Iraq was under the regime of Saddam Hussein who was one of the most prominent leaders in the Middle East, and even in the world. Therefore, as President Bush confirmed in 2001, Saddam Hussein and his government was a threat to American security and other countries.

As a realization of war on terrorism, on March 20, 2003, the U.S. government led an air raid over Baghdad. The attack triggered the Persian Gulf War of 2003 which was also known as the Operation Iraqi Freedom or the Iraq War.

The Iraq War was the second battle between the U.S. and Iraq. Previously, the coalition of army from 39 countries led by the U.S. and the UN defeated Iraq in the Gulf War II in 1991. Among the resolution that ended the Gulf War II was Iraq agreed to destroy its WMD (including its biological, chemical and nuclear weapons and all the supporting facilities). Eventually, Iraq disregarded this resolution.

After the fall of Saddam Hussein regime, the coalition led by the U.S. formed the Coalition Provisional Authority (CPA) as the provisional government in Iraq. By sending military invasions to conquer Iraq, capturing Saddam Hussein and creating the puppet government under the CPA, the U.S. government claimed to promote a

\footnotetext{
2 George W. Bush, "Freedom at war with fear", quoted from http://www.whitehouse.gov/ news/releases/2001/09/20010920-8.html, accessed on August 5, 2007
} 
better political environment, which was democratic and respecting human rights, in Iraq. Meanwhile, the U.S. army kept hunting for Saddam Hussein who successfully escaped. Finally, Saddam was captured on December 13, 2003 in Ad-Dawr.

Based on article 4 of the Geneva Convention III concerning the Treatment of Prisoner of War, Saddam Hussein was given the status of Prisoner of War (POW) and as stated in article 9, he should be protected by the International Committee of the Red Cross (ICRC). ${ }^{3}$ Saddam had not been charged with any crime although he was accused of conducted crimes against his own people during his regime. The ICRC argued that a prisoner of war who was suspected of crime should not be released; instead he had to be sent to the trial. ${ }^{4}$

The Security Council's resolution No. 1483 (2003) ${ }^{5}$ mandated Iraqis to form the government themselves but the Coalition army would stay to keep the peace. After that, prisoners of war should be handed over to the Iraqi government and be processed according to Iraqi's laws. The debate heated since the U.S. had not decided where Saddam Hussein would be put on trial.

Theoretically, Saddam Hussein ought to be sent to the trial in accordance with his crimes for the sake of law supremacy. Sharon Otterman wrote an article published in Council on Foreign, December 17, 2003, ${ }^{6}$ explaining that Saddam would face a charge of core crimes which is under the jurisdiction of the International Criminal Court (ICC). However, the American government as the captor decided to send him to the Supreme Iraqi Criminal Tribunal, well known as the Iraqi Special Tribunal. In

\footnotetext{
3 "Geneva Convention Relative to the Treatment of Prisoners of War of August 12, 1949", The Geneva Conventions of August 12 1949, ICRC: Geneva

4 "Berbagai Kemungkinan Pengadilan Saddam”, quoted from http://www.suaramerdeka.com/ harian/0406/21/opi2.htm, accessed on August 5, 2007

5 Based on "Coalition Provisional Authority Regulation Number 1" signed by L. Paul Bremer, quoted from http://www.cpairaq.org/ regulations/ 20030516_CPAREG_1_ The_Coalition_Provisional_Authority_pdf, accessed on August 13, 2007, 12:45

${ }^{6}$ Trias Kuncahyono (2005), Bulan Sabit di Atas Baghdad, Jakarta: Penerbit Buku Kompas, pp. 232-233.
} 
the end, Saddam Hussein was sentenced to death for the murder of 148 Shiites in Dujail in 1982 which was categorized as genocide.

Learning from the previous international crime cases, such as that of the leader of the ex-Yugoslavia, Slobodan Milosevic which was sent to the International Criminal Tribunal for ex-Yugoslavia (ICTY) in The Hague, the Netherlands, in 1993 or that of the International Criminal Tribunal for Rwanda (ICTR) in Arusha, Tanzania in $1994 ;^{7}$ Saddam Hussein should be put under the same legal system, that was under the International Criminal Court.

Apparently, there had been an anomaly in the case of Saddam Hussein. The ICC, which according to international laws was competence of this case, was not given the mandate by the UN. Instead, a local court namely the Iraqi Special Tribunal agreed by the U.S. to take over the case. Despite its authority as the international organization that facilitate international negotiations regarding international laws, security, economic and social problems, the UN remained silent concerning Saddam Hussein's case.

Saddam's trial was viewed as unjust by some people and this tragedy had result two big questions; how would good world governance be formed while the American Imperial hegemony over international politics remained? How should the establishment of a just world where violence is not proposed as a solution of problems be started?

\section{B. Good World Governance and International Politics}

The concept of Good Governance is established from the concept of Good Corporate Governance (GCG), a technical definition in economy which is developed to be a governmental term. Good governance can be defined as the process of creating a balance power and authority in the society which may influence the public

\footnotetext{
7 Andari Karina Anom (2006), "Dari Nuremberg sampai Bagdad”, Tempo, 13-19 November, p. 134; Romli Atmasasmita (1998), Kapita Selekta: Hukum Pidana Internasional, Bandung: Putra A Bardin, p. 12
} 
policies and socio economical development. Therefore, good governance requires an ongoing process of accommodating and mediating conflicts of interest within the community to reach a mutual decision. ${ }^{8}$

Governance in the perspective of state apparatus (good government, governance, good governance) refers to the authoritative people regarding political, economical and administrative matters in managing the state matters, mechanism, process and relationship among people and groups in the society. Governance is needed to maintain the rights and obligation of the citizens as well as mediating and facilitating conflicts of interest. In this article, GCG is described as the concept that explains the political structure of countries, later on known as good world governance.

The states system has three main pillars i.e. economic governance, political governance and administrative governance. The economic governance covers the process of decision making which is directly or indirectly influence the states economy. The second pillar, political governance, refers to the decision making process and the implementation of state policies legally by the legislative, executive and judicative. Administrative governance, as the last, is the system of policies implementation which opens the possibility to create an efficient, balance, accountable and fair public sectors.

In order to achieve good governance, in this case good world governance, there are at least eight characteristics that should be fulfilled by all nation-states. They are participation, consensus, accountability, transparency, responsiveness, effectiveness and efficiency, justice and inclusiveness, and law enforcement. ${ }^{9}$ From these requirements, it is clear that achieving good governance in the international context or

${ }^{8}$ Ardiansyah Samsura (2002), Participatory Planning, Good Governance, and Civil Society, Forum Pengembangan Partisipasi Masyarakat (FPPM), as quoted by Amir Faisol (2006), "Agama Dan Penyelenggaraan Pemerintahan Yang Baik", Millah, Vol V, No. 2, Yogyakarta: Magister Studi Islam UII, p. 157

9 "What Is Good Governance", cited from http://www.unescap.org/pdd/prs/ProjectActivities/ Ongoing/gg/governance.asp., accessed on August 16, 2007 
good world governance is not easy. However, it is not an impossible mission as long as every nation-state has a strong commitment to reach it.

Concerning the concept of international politics, it is the relationship between one country and another or in another word international politics is international relationship in which states is the actor and addressing high politics issues. ${ }^{10}$

\section{The U.S.: an Imperial hegemony}

1. The U.S. under George W. Bush's presidency

The U.S. presidency is one of the most powerful positions in the world. As mentioned in the U.S. Constitution, the president as a federal official is responsible for the U.S. relationship with other countries. ${ }^{11}$

Zbigniew Brzezinski views the U.S. as the global stability guard but at the same time its people institute a social construct which destroy national sovereignty. Another viewpoint shows that the U.S. manipulates the world politics since it is the biggest arms merchant in the world. ${ }^{12}$

The year 2004 was the second period of Bush presidency. He was elected as the $43^{\text {rd }}$ USA president in 2001. Supporting by the Republic Party, Bush won over Al Gore from the Democratic Party in the electorates votes but lost in the popular votes.

The 2000 General Election was the fourth event in American history when the winner of the election lost during the popular votes. ${ }^{13}$ Under Bush presidency, the

${ }^{10}$ Excerpt from David A. Lake and Patrick M. Morgan (1992), Regional Order Building Security in a New World, United States of America: Pennsylvania State University Press, pp. 125-139

${ }^{11}$ Garis Besar Pemerintahan Amerika Serikat 2000, Office of International Information Programs, United States Department of State, pp. 53-54

${ }^{12}$ Peter J. Katzenstein (2005), “Conclusion: National Security in a Changing World”, in Peter J. Katzenstein (ed.), The Culture of National Security: Norm and Identity in World Politics, in Suzie Sudarman "Norma-norma, Identitas, dan Politik Luar Negeri AS Periode ke-2 Bush", Jurnal Studi Amerika, Vol. X No. 2, July-December, Pusat Kajian Wilayah Amerika, University of Indonesia, Jakarta, p. 42.

13 The former three presidents who won the election but lost in the popular votes were John Quincy Adams (1824), Rutherford B. Hayes (1876), and Benjamin Harrison (1888). It is interesting to know that Bush was one of two USA presidents whose father was a former president. Bush father, George Herbert Walker Bush (Bush Sr.) became the U.S. president during 1989 until 1993. The other 
U.S. foreign politics paid more attention to high politics issues and used realistic approach to support its assumption that violence should be confronted with the same ferocity. This approach was in line with the Republic Party foreign politics paradigm which supports absolute military superiority. ${ }^{14}$

2. The U.S. foreign policy after the September 21, 2001 tragedy

Bush had not become the president for one year when the U.S. faced a major crisis on September 11, 2001, the worse terrorism attack in the U.S. history. The World Trade Center in New York and the Pentagon Building near Washington D.C. were attacked. The U.S. government blamed Osama bin Laden's organization, Al Qa'ida, as the responsible terrorist group for the raid.

There are several major foreign policies applied by the U.S. government after the $9 / 11$ tragedy: ${ }^{15}$

a. Military Action. The U.S., allied with British and Australia, formed a coalition for the sake of war on terrorism. The coalition has the authority to impose economic embargo and military raid upon suspected to be terrorist hideout countries. The raid had caused the U.S. foreign policies looked aggressive.

b. Homeland Security. George W. Bush established Department of Homeland Security which was responsible for monitoring and managing national security in order to fight against terrorism. Bush also rose up the military and homeland security budget by reducing other sector's, such as social programs.

c. Arms Control. On June 13, 2002, the U.S. withdrew from Antiballistic Missile Treaty, a pact that regulates missile defense system of a country. This withdrawal was an excuse for the U.S. to develop its antimissile system. The U.S.

father and son pairing were John Adams (1797-1801) and John Quincy Adams (1825-1829). "Bush, George Walker (Article Updates)" (2005), The World Book Multimedia Encyclopedia, World Book, Inc. 233 North Michigan Avenue Suite 2000 Chicago, Illinois 60601.

${ }^{14}$ Bambang Cipto (2003), Politik dan Pemerintahan Amerika, Yogyakarta: Lingkaran, p. 60

${ }^{15}$ Excerpt from "Bush's Administration" (2005), The World Book Multimedia Encyclopedia, World Book, Inc. 233 North Michigan Avenue Suite 2000 Chicago, Illinois 60601 
government argued that this project was necessary to protect American from another terrorist attack.

d. War against Iraq. Since Saddam Hussein did not permit the UN to inspect Iraqi weaponry, the U.S. named Saddam Hussein's regime “a grave and gathering danger". Moreover, after the 9/11 tragedy, the U.S. accused Iraq of supporting international terrorist organization (Al Qa'ida). In 2003, the U.S. started the Iraq war, although the accusations of the existence of the WMD and the support for Al Qa'ida were not yet proven. However, Bush kept his decision and firmly stated that the invasion was a preemptive action because Saddam Hussein was a fierce dictator that should be overthrown.

\section{The 2003 Iraq War}

The discussion about the Iraq War cannot be separated from the establishment of the National Security Strategy of the United States of America (NSS 2002). NSS 2002 was the collection of Bush's speech before the U.S. Congress published by the White House on September 22, 2002. NSS 2002 had become the main security strategy for the U.S. after the 9/11 raid and its foreign policies' code in the time of terror. In NSS' foreword, Bush states that:

"Enemies in the past needed great armies and great industrial capabilities to endanger America. Now, shadowy networks of individuals can bring great chaos and suffering to our shores for less than it costs to purchase a single tank ...the events of September 11, 2001, taught us that weak states, like Afghanistan, can pose as great a danger to our national interests as strong states" $" 16$

His statement confirmed that the U.S. strategy has changed its direction since the Cold War. Currently, the U.S. pays much attention to the danger from terrorist groups instead of the countries that involved in the Cold War. This strategy implied

\footnotetext{
${ }^{16}$ President of the United States (2002), The National Security Strategy of the United States of America
} 
that Bush would launch the war on terrorism in his own way and neglecting international laws.

The U.S. presidents need the Congress' support for their foreign policies especially if it is related to the declaration of war. The U.S. Constitution regulates that the declaration of war is the Congress' authority. Furthermore, the Congress is the authoritative institution related to politics and national security. ${ }^{17}$

The Iraq War in 2003 started with the U.S. suspicion that Iraq has developed the WMD and supported Al Qa'ida. In addition, Bush labeled Saddam Hussein's regime as "a grave and gathering danger". Based on this accusation, the U.S. launched military raid over Iraq. As mentioned in the NSS 2002, the U.S. government could send military aggression to the suspected countries as a preemptive action for the sake of national security.

Fashioning foreign policies is not an easy decision for the U.S. president. There are several steps before the decision is reached. The main step is to get the Congress' agreement. Since the legislative is relatively more powerful than the executive, the U.S. Congress has the power to determine whether the president's proposal for the foreign policies is accepted or not. Therefore, Bush had to get the permission from the Congress to his resolution to use military force over Iraq. Finally, the resolution was approved by the Congress on November $2002 .^{18}$

The majority of American supported Bush's decision to launch military action to Iraq. However, his policy was criticized by people from other countries who considered the U.S. violated international laws by invading an innocuous country. Apparently, Bush defended his opinion by stating that the invasion was a preemptive action.

In fact, the invasion was the U.S.'s realization of the war on terrorism although it was not approved by the UN Security Council. On March 20, 2003, the U.S.

\footnotetext{
${ }^{17}$ Bambang Cipto, op.cit., p. 212

${ }^{18}$ Excerpt from "Bush's Administration", The World Book Multimedia Encyclopedia (2005), World Book, Inc. 233 North Michigan Avenue Suite 2000 Chicago, Illinois 60601.
} 
military led the coalition army to set off the air raid over Baghdad, the Capital city of Iraq. The raid instigated the Persian Gulf War 2003, often known as the Operation Iraqi Freedom or Iraq War 2003. This incident warned the world that the U.S. might start military raid without the UN or other countries approval.

\section{The Saddam Hussein's Trial and the Tragedy of Good World Governance}

1. The U.S.'s influence upon the Saddam Hussein's trial

The Saddam Hussein's arrest initiated a new debate among international society. The coalition army had to determine Saddam Hussein's legal status, drop the charge for his crimes, and decide the judicial process for him.

Concerning the legal status of Saddam Hussein, there were three possibilities i.e. prisoner of war, internee and political prisoner. ${ }^{19}$ Saddam Hussein could be granted the status of a prisoner of war if the coalition army classified him as an assailant who was seized by his enemy in an armed conflict. ${ }^{20}$ However, it was not likely Saddam Hussein would be given the status of prisoner of war since according to articles 118 and 119 of the Geneva Convention the coalition army had to release him as soon as the war was over. ${ }^{21}$

The status of internee would be given to a person or groups who involved in a conflict, resided in the enemy's territories and then captured by its administrative or military government. Once granted the status of an internee, Saddam Hussein ought to be detained in a peaceful place which guaranteed the chance for his family and the

${ }^{19}$ Excerpt from Andi Widjajanto (2007), “Komplikasi Hukum Tertangkapnya Saddam Hussein”, quoted from http://www.kompas.com/kompas-cetak/0312/17/Jendela/744944.htm, accessed on August 15, 2007, 15:18.

${ }^{20}$ Based on article 4 of The Geneva Convention III of the Treatment of Prisoners of War, Saddam Hussein was given the status of Prisoner of War (POW) and according to article 9 of the Geneva Convention III, he was protected by The International Committee of the Red Cross (ICRC), see "Geneva Convention relative to the Treatment of Prisoners of War of August 12, 1949 ", The Geneva Conventions of August 12, 1949, Geneva: International Committee of the Red Cross, pp. 76-79.

${ }^{21}$ See "Section II: Release and Repatriation of Prisoners of War at the Close and Hostilities" Articles 118 and 119, "Geneva Convention relative to the Treatment of Prisoners of War of August 12, 1949”, Ibid., pp. 123-125. 
International Committee of the Red Cross (ICRC) to visit him. This was a temporary status which depended on the possibility to put him on as a detainee. Another status, political prisoner, might be given if Saddam Hussein was viewed as a person who ought to be sent before the court for international crimes.

The legal status of Saddam Hussein related to the accusation of his crimes. He could be suspected as a violator of the Hague Convention IV 1907 of the Laws and Customs of War on Land. ${ }^{22}$ Specifically, Saddam Hussein might be charged with articles on war crimes and crimes against humanity.

On the other hand, based on the Rome Statute, Saddam Hussein could be charged with international crimes, at least in three charges. First, he could be charged with article 6 of the Rome Statute of genocide of a minority tribe, the Kurd. Secondly, he might be accused of crimes against humanity which according to article 7 of the Statute is under the ICC jurisdiction. During his regime, he was suspected of violation against human rights. The last, based on article 8 of the Statute he was accused of infringement upon laws of war, especially the Geneva Convention.

a. Alternative Trials for Saddam Hussein

There were several ideas proposed for the judicial process for Saddam Hussein, but most political observers thought that the choice inclined towards the U.S. trial but under Iraqi brand name. ${ }^{23}$

If Saddam Hussein was charged with one of those three international crimes, there are several courts which were competent to pass judgment on him. The judicial process done by the court should be based on universal jurisdiction for international crimes. Basically, universal jurisdiction gives the authority to any court to preside

${ }^{22}$ The Hague Convention IV (1907) on the Laws and Customs of War on Land, formally named The Convention Respecting to the Laws and Customs of War on Land is the completion of the Hague Convention II (1899) on the Laws and Customs of War on Land, see Arlina Permanasari et. al., (1999), Pengantar Hukum Humaniter, International Committee of the Red Cross, Jakarta, pp. 22-26.

23 “Arah Pengadilan Saddam: Sentuhan AS, tetapi Dikemas atas Nama Irak", Kompas, Thursday, (18 December 2003), http://www.kompas.com/kompascetak/0312/18/sorotan/753159.htm, accessed on August 16, 2007 
over international criminals. Some of the U.S.'s politician suggested that Saddam Hussein be processed by the U.S.'s military court. However, this suggestion would defy the U.S. testimonial that Iraqis were responsible for their own country after the Coalition Provisional Authority (CPA) return the sovereignty to the Iraqi Governing Council (IGC).

Another option was to turn Saddam over to the International Criminal Court (ICC) in The Hague, which had the competency to deal with crime against humanity, crime of wars and genocide. The U.S. government refused this idea since Iraq did not ratify the ICC. Obviously, the biggest reason was the ICC did not acknowledge death penalty. The U.S. refusal was also related to its unilateral interest.

The ICC might be activated using articles 13, 14 and 15 of the Rome Statute 1998. Article 13 authorizes the UN Security Council to turn Saddam Hussein over to the ICC while article 14 opens the possibility for a country (in this case the U.S. or another coalition country) to send Saddam Hussein to the ICC. Article 15, on the other hand, gives the ICC public prosecutor to take over Saddam Hussein's case.

The judicial process for Saddam Hussein would determine whether the U.S. intended to impose multilateralism in order to strengthen transnational society and humanity principals as stated in many transnational conventions, or otherwise.

Despite the competent court for Saddam Hussein's case, in the end the U.S.'s stand point would determine where Saddam Hussein's trial would be held since he was imprisoned in the U.S. The U.S.'s stance was mainly based on political considerations instead of juridical one.

In the end, the U.S. chose another alternative for Saddam Hussein's trial, the judicial system which was more advance in the discussion, the Iraqi Special Tribunal (IST), which was often regarded as the domestic solution. The IST was founded by the $\mathrm{CPA}^{24}$ through the enactment of the Iraqi Special Tribunal Statute which was

\footnotetext{
24 “Coalition Provisional Authority Order Number 48: Delegation of Authority Regarding an Iraqi Tribunal",CPA/ORD/9 Dec 2003/48 (2003) (IST Statute), IST
} 
announced on December 10, 2003. This alternative was not directly accepted by international society as the capability of Iraqi judges to administer a case as big as Saddam Hussein's was doubted. Another reason was this trial would not be free from the U.S.'s pressure despite its location in Iraq.

b. The U.S.'s pressure over the Iraqi Special Tribunal

The formation of the IST, politically, was a reasonable option for the U.S. even though other legal options were available. As the occupier of Iraq, the U.S. was anxious about Iraqi governmental system and its regulation. The U.S. tried to camouflage its hegemony over Iraq by letting the IGC to select the IST apparatus. ${ }^{25}$

George W. Bush affirmed that the IST was managed by Iraqish, as stated by Scott McClellan, the White House Spokesperson, that "Saddam Hussein is facing Iraqi justice". However, obviously, Saddam Hussein's trial was under the supervision of the CPA led by the U.S. ${ }^{26}$

In the UN's report for the World Bank - UNDG Legal Needs Assessment Mission to Iraq, August 2003 - the Human Right Watch (HRW) concluded that the judges, prosecutors, and attorneys of the IST were not capable of a complicated judicial process such as Saddam Hussein's case for they were lack of necessary knowledge.

Consequently, the IST would depend on foreign country's assistances. ${ }^{27}$ Aside from human resource aids, the IST was also called for monetary funds. In fact, as the

25 "Tribunal Kejahatan terhadap Kemanusiaan di Irak", cited from http://www.ranesi.nl /arsipaktua/timurtengah/irak/tribunal_irak.html, accessed on July 12, 2007

26 Cited from http://www.globalpolicy.org/intljustice/tribunals/iraq/2005/1019fairness.htm, accessed on July 14, 2007, 16:1

${ }^{27}$ It was reported to the U.S. Congress that "Currently, Iraq lacks the professional and technical investigative and judicial expertise to [prosecute crimes against humanity and war crimes] on its own, and therefore needs Coalition assistance": Department of State, Quarterly Update to Congress: Section 2207 Report on Iraq Relief and Reconstruction (January 2004), p. 43, cited in The Former Iraqi Government on Trial, A Human Right Watch Briefing Paper, October 16, 2005, p. 17, quoted from http://hrw.org/backgrounder/mena/iraq1005/iraq1005.pdf, accessed on July 27, 2007, 12:56 
head of the coalition army for Iraq, the U.S. donated US\$ 75 millions in 2003 for the investigation and trial for Saddam Hussein's regime. The aid has been raised up to US\$ 128 millions. ${ }^{28}$ The money was given via the U.S. Embassy's Regime Crimes Liaison Office (RCLO). Although the U.S. declared that they merely assisted the IST Statute, the RCLO three-monthly report before the U.S. Congress, showed that more than 50 RCLO's workers played important role in the IST, including set the court room, led the investigation, questioned the detainees, checked the confiscated documents and gathered the evidences, and trained the IST's staff.

For more that one year, the U.S. had supported the IST, very intense compare to support from other countries or the UN, in order to maintain the legitimacy of the IST and avert suspicion that the trial was dominated by the U.S. Unfortunately, it was difficult for the IST to obtain help from other countries because of several reasons; the death penalty imposed by the IST, the erratic security in Iraq, and the U.S.'s domination of the IST. ${ }^{29}$ The fact that the IST depended on the U.S.' aid had reduced its liability. According to the New York Times, the RCLO provided the IST with attorneys and experts on international law from the coalition countries, especially Britain and Australia, which were "the real power behind the tribunal".

2. The benefit of Saddam Hussein's trial in the IST to the U.S.

The decision to hand over Saddam Hussein's judicial process to the IST was based on its benefit to the U.S. Assessed from political point of view, the U.S. would benefit from the trial in the IST compare to that in the ICC.

a. The U.S.'s political interest in the IST

By assigning the IST to hold Saddam Hussein's judicial process, the U.S. attempted to preserve the balance between the ideas of unilateralism and

${ }^{28}$ Cited from Department of State, Quarterly Update to Congress: Section 2207 Report on Iraq Relief and Reconstruction (January 2004), p. 43 and (April 2005), p. 30, Ibid.

${ }^{29}$ Comments given by the Chair of RCLO, Greg Kehoe (2005), "A Slow Search for Justice in Iraq", Legal Times, 24 January; Department of State, Quarterly Update to Congress: Section 2207 Report on Iraq Relief and Reconstruction (July 2004), Ibid. 
multilateralism. In one hand, the U.S. maintained its position as the leader of many multilateral international institutions. On the other hand, the U.S. demanded to safe guard its freedom to act unilaterally.

Thus, the U.S. yearned for control over the IST to prevent interventions from any organizations, even the UN, with the intention to keep the U.S. unilateral freedom. As a result, the trial in the IST was easily controlled by the U.S. since the Iraqi government after the fall of Saddam Hussein's regime was basically the puppet government.

Since the court imposed death penalty, Saddam Hussein might be sentenced to death and the puppet government controlled by the U.S. could be instituted. There would not be suspicion that the U.S. intervened in the judicial process since the trial was held in Iraq. Handing over the trial to the IST was the right decision.

Learning from the past experience, the judicial process in the ICC took a long time and the U.S. could not affect its trial. Thus, this kind of trial would put the U.S. off unilateral actions. Moreover, the U.S. was afraid that the Rome Statute might institute the international prosecutors with wide competence and free from the UN Security Council's intervention, so that even American citizens might be judged in the ICC. Another motive behind the U.S. preference was the ICC would dig up the connection between the U.S. and Saddam Hussein's regime in the past.

b. The U.S.'s opposition to the ICC

According to the U.S.'s government, international laws are not binding for every country. If the international law contradicts the national interest of a country, that country could pass a law to protect its interest and disregard the international law. In this case, the winner would be the national law although that country has already ratified the international law.

The U.S. had been in defiance of the ICC since the Republic Party and George W. Bush entered the White House. The resistance was confirmed by the U.S.'s 
Ambassador for the UN in the mid 2001. ${ }^{30}$ Previously, under Bill Clinton's presidency, the U.S. signed the pact of the foundation of the ICC. Later on, Bush annulled the signature and refused any international provision over the U.S.'s army. He feared that the ICC would investigate the U.S.'s army for political reasons. Furthermore, the U.S. refused to acknowledge an international judicial institution's authority over its own.

The main reason behind the U.S.'s opposition to the Rome Statute was the authority of the ICC to impose its jurisdictions over countries which ratified the ICC. The U.S. urged the ICC to implement its jurisdiction as long as the country of the suspect's nationality had ratified the ICC jurisdiction.

Aside of the main reason above, the U.S. had several other grounds: ${ }^{31}$

First, when the idea of the establishment of the ICC was proposed, the U.S. intended to keep the balance between unilateralism and multilateralism. The unilateral interest of the U.S. was the freedom to conduct unilateral acts, for instance invaded Iraq in 2003 without the UN agreement. The multilateral interest of the U.S., in the other hand, was kept its position as the head of international institutions which are multilateral, such as the UN, NATO and other organizations.

In the institution of ad hoc tribunals (in this case was the IST), this demand was not conspicuous since it was the realization of the U.S.'s unilateral freedom. Once the IST given an institutionalized and permanent authority over Saddam Hussein's case, it would suppress the U.S.'s unilateral freedom.

Secondly, although the U.S. did not defend international criminals, its government would never let the U.S. citizens facing any international tribunals. An ad hoc and restricted territory tribunal could be controlled not to affect the U.S. citizens

${ }^{30}$ Eddy Djunaedi (1998), “Mengapa AS Tidak Setuju dengan Statuta ICC?”,Varia Peradilan, Majalah Hukum Tahun XVI No. 184

31 As stated by the UN's Ambassador, Scheffer on 23 July 1998 before the U.S. Congress Commission for foreign affairs, Ibid. 
while in a permanent and universal tribunal such as the ICC, such kind of control would be difficult to be forced.

The last, it might be possible that the Rome Statute would generate independent prosecutors with wide authority. Actually, the Rome Statute does not authorize the ICC public prosecutor to do an independent investigation into the national authority, but rather the prosecutor was licensed to ask state party's cooperation and aid in accordance with the Statute and laws of each state party. Obviously, this regulation would legitimize state party's deviation. The U.S. could possibly limit the access of the public prosecutor to its citizens.

In the U.S.'s opinion, the public prosecutor should ask permission from the UN's Security Council before open the investigation. Evidently, the U.S. would benefit from this proposition since the U.S. can veto the decision of the UN's Security Council. Therefore, the U.S. struggled against the formation of the ICC.

\section{c. The U.S.'s compulsion on the UN}

The institution of the ICC was strongly resisted by the U.S. On June 30, 2002, one day before the ICC officially came into operation; the U.S. vetoed the UN's peace resolution for Bosnia to remonstrate the Security Council's rejection to exempt the Peace Keeping Force from the ICC's authoritative. The U.S. government used its political power to force the members of the Council to shield the U.S. from article 12 of the Rome Statute. The article 12 states that the ICC has the jurisdiction over a crime as long as the country where the crime took place or the country where the criminal is the citizen is a State Party. Consequently, the Peace Keeping Force from non State Party, which was assigned in a State Party where a crime occurred, might run the risk of prosecuted by the ICC provided that the crime was under the jurisdiction of the ICC. Notably, the Peace Keeping Force in which the U.S.'s army was the majority was for the U.S. and international's benefit.

For that very reason, Bush's government threatened the UN with the withdrawal of the U.S.'s Army from Bosnia. The UN surrendered to the threat because the 
withdrawal of the U.S.'s army most likely weakened the peace keeping force in Bosnia. Nevertheless, the U.S. provided the UN's peace keeping force with significant number of military personnel and a lot of money. In the end, the U.S. succeeded in making use of the circumstances in Bosnia. The UN's Security Council agreed to give the capitulation right for one year to the U.S.'s army. In July 2003, the UN extended the resolution for one more year. However, in July 2004, the UN could not abide the pressure from the U.S. The UN considered the extension of the resolution as an insult to the UN's authority.

\section{d. The U.S.'s Invasion Act}

In June 2003, once more, the U.S. gained another exception from the UN. By showing a total disregard to the popular demand, the U.S. guaranteed its army and officials that they were immune from any edict. Furthermore, the U.S. government issued the Hague Invasion Act to free its citizens which were apprehended in The Hague. This event proved that the U.S.'s military were the criminals of war and human rights' violators.

\section{The U.S.'s domination: a Good World Governance hindrance}

The cases mentioned above clearly show that the U.S. prioritizes its unilateral stand point. Despite its claim as the democratic country in the world and its propaganda for democracy and human rights, the U.S. has defied the UN's existence, especially the ICC.

As explained above, there are, at least, 8 requirements to achieve good governance, or in this case good world governance; participation, consensus, accountability, transparency, responsiveness, effectiveness and efficiency, justice and inclusiveness, and law enforcement. In order to understand the concept of good world governance, we have to start from the existence of the UN as the manifestation of the world governance where countries all over the world delegate their representatives. In this international institution, every nation-state in the world entrust its hope for the 
establishment of good world governance although in fact the UN has not yet succeeded. There are several obstacles faced by the UN for the achievement of good world governance but the major problem is the difficulty to enforce the international law supremacy. The resolution of the Iraqi case done by the U.S., which is a state and not an international institution, evidently showed the inferiority of the UN to the U.S. Justice and international law enforcement, as one unity of the requirements for good world governance was impossible to be accomplished if the world is under the U.S.'s hegemony.

Learning from Iraqi cases, especially Saddam Hussein's trial, it is clear that the UN was inferior to the U.S.'s power. Even though majority of the UN's members disagreed with the military raid upon Iraq, more specifically Saddam Hussein's judicial process in the Iraqi Special Tribunal, the UN could not do anything. The U.S.'s foreign policy after the WTC tragedy i.e. pre-emptive action and unilateral to the "suspected" terrorist countries, had led to another big problem, good world governance becomes difficult to be obtained. Finding the resolve to gain the same bargaining position with the U.S. is not merely the UN's problem but also that of every nation-state in the world. Once the same bargaining position is achieved, a just and tolerant society would be attained.

\section{E. Conclusion}

From the discussion above, two points can be generated; first, Saddam Hussein's judicial process which was viewed as violating international laws evidently showed that the U.S.'s unilateral actions by attacking other country, in this case was Iraq, for the sake of war on terrorism, and the U.S.' hegemony over the world is a big hindrance for the establishment of good world governance. The second, the process of creating a global society in which social justice is assured and confrontation is not considered as a conflict resolution would be acquired once the UN as the manifestation of countries in the world is independent and has the stronger bargaining position over the U.S.'s dominance. 


\section{BIBLIOGRAPHY}

Andari Karina Anom (2006), "Dari Nuremberg sampai Bagdad" in Tempo 13-19 November .

Andi Widjajanto (2007), "Komplikasi Hukum Tertangkapnya Saddam Hussein” on http://www.kompas.com/kompas-cetak/0312/17/Jendela/744944.htm

Bambang Cipto (2003), Politik dan Pemerintahan Amerika, Yogyakarta: Lingkaran.

Bremer, L. Paul dikutip http://www.cpairaq.org/ regulations/ 20030516_CPAREG_1_The_Coalition_Provisional_Authority.pdf

Bush, Goerge W., "Freedom at war with Fear" on http://www.whitehouse.gov/ news/releases/2001/09/20010920-8.html.

Coalition Provisional Authority Order Number 48: Delegation of Authority Regarding an Iraqi Tribunal”,CPA/ORD/9 Dec 2003/48 (2003) (IST Statute), IST.

Department of State, Quarterly Update to Congress: Section 2207 Report on Iraq Relief and Reconstruction (January 2004)

Eddy Djunaedi (1998), “Mengapa AS Tidak Setuju dengan Statuta ICC?” in Varia Peradilan, Majalah Hukum XVI No. 184

Garis Besar Pemerintahan Amerika Serikat (2000), Office of International Information Programs, United States Department of State

Geneva Convention Relative to the Treatment of Prisoners of War of August 12 1949", The Geneva Conventions of August 12 1949, ICRC, Geneva

http://www.globalpolicy.org/intljustice/tribunals/iraq/2005/1019fairness.htm.

http://www.ranesi.nl /arsipaktua/timurtengah/irak/tribunal_irak.html

http://www.suaramerdeka.com/ harian/0406/21/opi2.htm

Ikenberry, G. John (2004), "Illusions of Empire: Defining the New American Order", in Foreign Affairs, Vol. 83, No. 2, March/April 2004

Katzenstein, Peter J., (2005) "Conclusion: National Security in a Changing World" in Peter J. Katzenstein (ed.), The Culture of National Security: Norm and Identity in World Politics,

Suzie Sudarman, "Norma-norma, Identitas, dan Politik Luar Negeri AS Periode ke-2 Bush" in Jurnal Studi Amerika, Vol. X No. 2, Juli-Desember, Pusat Kajian Wilayah Amerika Universitas Indonesia, Jakarta

Kehoe, Greg (2005), “A Slow Search for Justice in Iraq” in Legal Times, 24 January; Department of State, Quarterly Update to Congress: Section 2207 Report on Iraq Relief and Reconstruction 
Kompas, Kamis, (18 Desember 2003), Arah Pengadilan Saddam: Sentuhan AS, tetapi Dikemas atas Nama Irak, on http://www.kompas.com/kompascetak/0312/18/sorotan/753159.htm

Konvensi Genewa III mengenai Perlakuan terhadap Tawanan Perang, Convention relative to the Treatment of Prisoners of War of August 12 1949, The Geneva Conventions of August 12 1949, Geneva: International Committee of the Red Cross

Konvensi IV Den Haag (1907) mengenai Hukum dan Kebiassan Perang di Darat (Convention Respecting to the Laws and Customs of War on Land) a revision of Konvensi II Den Haag (1899) mengenai Hukum dan Kebiasaan Perang di Darat, in Arlina Permanasari et.al. (1999), Pengantar Hukum Humaniter, International Committee of the Red Cross, Jakarta

Lake, David A., and Patrick M. Morgan (1992), Regional Order Building Security in a New World, United States of America: Pensylvania State University Press

Amir Faisol, (2005), "Agama dan Penyelenggaraan Pemerintahan yang Baik" in Millah, Vol V, No. 2, Yogyakarta: Magister Studi Islam UII

President of the United States (2002), The National Security Strategy of the United States of America

Romli Atmasasmita (1998), Kapita Selekta: Hukum Pidana Internasional, Bandung: Putra A Bardin

The Former Iraqi Government on Trial, A Human Right Watch Briefing Paper, http://hrw.org/backgrounder/mena/iraq1005/iraq1005.pdf

The World Book Multimedia Encyclopedia 2005 World Book, Inc. 233 North Michigan Avenue Suite 2000 Chicago, Illinois 60601

Trias Kuncahyono (2005), Bulan Sabit di Atas Baghdad, Jakarta: Penerbit Buku Kompas. 